\title{
Prevalence of Glucose 6-Phosphate Dehydrogenase Variants in Malaria-Endemic Areas of South Central Timor, Eastern Indonesia
}

\author{
Novi Sulistyaningrum, ${ }^{1,2}$ Dona Arlinda, ${ }^{1,2}$ Jontari Hutagalung, ${ }^{2}$ Sunarno Sunarno, ${ }^{2}$ Intan Sari Oktoberia, ${ }^{2}$ Sarwo Handayani, ${ }^{2}$ \\ Riyanti Ekowatiningsih, ${ }^{2}$ Endah Ariyanti Yusnita, ${ }^{2}$ Budi Prasetyorini, ${ }^{2}$ Aulia Rizki, ${ }^{2}$ Emiliana Tjitra, ${ }^{3}$ Kesara Na-Bangchang, ${ }^{1}$ and \\ Wanna Chaijaroenkul ${ }^{1 *}$ \\ ${ }^{1}$ Chulabhorn International College of Medicine (CICM), Thammasat University (Rangsit Campus), Patum Thani, Thailand; ${ }^{2}$ National Institute of \\ Health Research and Development, Ministry of Health, Republic of Indonesia, Jakarta, Indonesia; ${ }^{3}$ St. Carolus Hospital, Jakarta, Indonesia
}

\begin{abstract}
Primaquine is an effective anti-hypnozoite drug for Plasmodium vivax and Plasmodium ovale. However, it can trigger erythrocyte hemolysis in people with glucose 6-phosphate dehydrogenase (G6PD) deficiency. In a previous report from South Central Timor (SCT), Indonesia, we described the prevalence of Vanua Lava, Chatham, and Viangchan variants; in this study, other G6PD variants (Kaiping, Coimbra, Gaohe, Canton, and Mahidol) were subsequently analyzed. For clarity, all of these results are described together. The 381 DNA samples from the previous study during 2013-2014 were analyzed for G6PD variants by using PCR-restriction fragment length polymorphism (RFLP). The prevalence of G6PD deficiency in SCT was $6.3 \%$ (24/381 cases), including $4.2 \%$ (16/381 cases), $0.5 \%$ (2/381 cases), and 1.6\% (6/381 cases) for Coimbra, Kaiping, and Vanua Lava variants, respectively. No other variants were found in this population. A significant association was found between ethnicity and the distribution of G6PD Kaiping in female subjects. A positive association was shown between G6PD activity and heterozygous females carrying Coimbra genotype, hemizygous males carrying Vanua Lava, Plasmodium falciparum infection in female subjects, and $P$. vivax infection in male subjects. Further molecular analysis of heterozygous females, particularly in malaria-endemic areas, is needed for mapping distribution of G6PD deficiency status in Indonesia.
\end{abstract}

\section{INTRODUCTION}

The Ministry of Health of the Republic of Indonesia plans to eliminate malaria by $2030 .^{1}$ The malaria incidence in Indonesia has declined from an annual parasite incidence of $1.8 \%$ $\left(422,447\right.$ cases) in $2011-0.8 \%$ (218,450 cases) in 2016 . $^{2}$ Despite such a decline, there remain problems in achieving malaria elimination in Indonesia. Major obstacles include the emergence of antimalarial drug resistance, mosquito resistance to insecticides, and inadequate health system performance. ${ }^{3-5}$ The predominant malaria species are Plasmodium falciparum and Plasmodium vivax, with prevalences of $62 \%$ and $33 \%$, respectively. ${ }^{6}$ Among patients hospitalized with a primary diagnosis of malaria, vivax and falciparum malaria patients are often equally likely not to survive. Severe $P$. vivax infection has been reported from various endemic regions, with a similar risk of death to that of $P$. falciparum infection. ${ }^{7}$ Chloroquine-resistant $P$. vivax was first reported in 1989, almost 30 years after chloroquine-resistant $P$. falciparum was first noted. Declining efficacy of chloroquine against $P$. vivax was reported in $P$. vivax-endemic areas of the world, including Indonesia. ${ }^{8-12}$ Some countries have, therefore, revised their national antimalarial guidelines to recommend artemisinin-based combination therapy (ACT) for the treatment of both $P$. falciparum and $P$. vivax infections. Currently, the Indonesian Ministry of Health recommends dihydroartemisininpiperaquine (DHP) in combination with primaquine for radical cure of all $P$. vivax cases. ${ }^{13}$

Primaquine is a potent antimalarial drug for blocking the transmission of $P$. falciparum infection and preventing the relapse of $P$. vivax hypnozoites. Nevertheless, the concern of its clinical use is the risk of intravascular hemolysis, particularly in individuals with glucose 6-phosphate dehydrogenase

\footnotetext{
*Address correspondence to Wanna Chaijaroenkul, Chulabhorn International College of Medicine, Thammasat University (Rangsit Campus), 99 Moo 18 Phaholyothin Rd., Klong Luang District, Pathum Thani 12121, Thailand. E-mail: wn_ap39@yahoo.com
}

(G6PD) deficiency. The WHO recommends primaquine at a dose of $0.25-0.5 \mathrm{mg}$ per $\mathrm{kg}$ body weight be given daily for 14 days in all $P$. vivax patients with normal G6PD activity. ${ }^{14}$ Glucose 6-phosphate dehydrogenase testing is not usually available in most malaria-endemic areas of the world, and, therefore, lower doses of primaquine are recommended to reduce the risk of drug-induced hemolysis. ${ }^{15,16}$ In Indonesia, the recommended dose regimen for $P$. vivax patients with normal G6PD activity is $0.25 \mathrm{mg} / \mathrm{kg}$ daily for 14 days, with an increase to $0.5 \mathrm{mg} / \mathrm{kg}$ daily for 14 days in case of relapse. For those who are suspected of G6PD deficiency, primaquine is given at a dose of $0.75 \mathrm{mg} / \mathrm{kg}$ per week for $8-12$ weeks. ${ }^{13,17}$ Testing for G6PD deficiency before primaquine treatment of patients with $P$. vivax malaria cannot be routinely applied in malaria-endemic areas because of the time-consuming procedure, and the requirement of specialized equipment and laboratory skills. ${ }^{18}$ Administration of primaquine without information on G6PD status may lead to an acute hemolytic anemia attack in patients with G6PD deficiency, as well as to increased morbidity from $P$. vivax infection. ${ }^{19}$ Mapping of G6PD deficiency variants in malaria-endemic populations is therefore essential to support the Indonesian malaria elimination program.

Glucose 6-phosphate dehydrogenase deficiency is the most common genetic disorder found in Southeast Asia, especially in malaria-endemic areas. It has been claimed to be a protective factor against malaria infection. ${ }^{20}$ The gene encoding the G6PD enzyme consists of 1,545 base pairs separated into 13 exons. Almost all types of G6PD deficiency are caused by a single nucleotide mutation, resulting in the change of one amino acid change among a total of 515 amino acids. ${ }^{21,22}$ At least 217 mutations in the G6PD gene have been reported around the world. ${ }^{23}$ The G6PD gene is located on the X-chromosome, and, therefore, females can carry either homozygous or heterozygous genotypes, but males can only carry hemizygous genotypes. $^{19}$

In Eastern Indonesia, the common reported G6PD variants are Vanua Lava $(10884 \mathrm{~T}>\mathrm{C})$, Viangchan $(871 \mathrm{G}>\mathrm{A})$, Chatham $(1003 \mathrm{G}>\mathrm{A})$, Kaiping $(1388 \mathrm{G}>\mathrm{A})$, and Coimbra 
(592C>T). ${ }^{21,22,24,25}$ In a previous report (2013-2014) from South Central Timor (SCT), Indonesia, three G6PD variants (Vanua Lava, Chatham, and Viangchan) were analyzed. The Vanua Lava variant $(10884 \mathrm{~T}>\mathrm{C})$ was the most common variant $(6.5 \%, 6 / 92$ cases), whereas Chatham $(1003 \mathrm{G}>\mathrm{A})$ and Viangchan $(871 \mathrm{G}>A)$ variants were absent. ${ }^{24}$ To enrich the data on G6PD status in SCT, other G6PD variants (Kaiping, Coimbra, Gaohe, Canton, and Mahidol) were subsequently analyzed in this study. For clarity, all of these results are described together.

\section{MATERIALS AND METHODS}

Study design and samples. This study was conducted in Jakarta, Indonesia, from 2018 to 2019 . Stored DNA samples collected from the previous study (2013-2014) in the SCT district, Eastern Indonesia, ${ }^{24}$ were selected by purposive sampling with background demographic data fulfilling at least one of the following three criteria: 1) asymptomatic malaria (confirmed by PCR), 2) G6PD deficiency (G6PD level $<6.97$ $\mathrm{U} / \mathrm{gHb}$ by Randox test), or 3 ) anemia (hemoglobin level $<13 \mathrm{~g} /$ $\mathrm{dL}$ in males and $<11 \mathrm{~g} / \mathrm{dL}$ in females). A total of $381 \mathrm{DNA}$ samples were finally included in the analysis (from 156 males and 225 females). The background demographic data from the previous study ${ }^{24}$ were analyzed to investigate their association with G6PD variant status.

DNA extraction. Archived DNA samples (at $-80^{\circ} \mathrm{C}$ ) had previously been extracted from whole blood samples $(200 \mu \mathrm{L}$ each) by using the Nucleon Genomic DNA Extraction kit (Promega, Madison, WI). ${ }^{24}$

Genotyping of G6PD variants. The five common G6PD variants found in Indonesia, that is, Coimbra (592C>T), Gaohe $(95 A>G)$, Canton (1376G $>T)$, Mahidol (487G $>A)$, and Kaiping $(1388 \mathrm{G}>\mathrm{A})$, were analyzed using PCR-RFLP according to the modified methods provided in Table 1. The primer pairs and appropriate restriction enzymes used in the analysis are presented in Table 1. Briefly, PCR mixtures $(25 \mu \mathrm{L})$ consisted of 2 $\mu \mathrm{L}$ of DNA solution, $1 \times$ buffer with $\left(\mathrm{NH}_{4}\right)_{2} \mathrm{SO}_{4}, 0.2 \mu \mathrm{M}$ of each primer, $200 \mu \mathrm{M}$ each dNTP, $2 \mathrm{mM} \mathrm{MgCl} 2$, and $1 \mathrm{U}$ of Taq polymerase. The amplification process was performed using a Bio-Rad C1000 thermal cycler with the conditions summarized in Table 1. The PCR product was digested with the restriction enzymes indicated in Table 1. The targeted band was identified under UV light using a Bio-Rad molecular imager, gel doc XR+ (Bio-Rad Laboratories, Inc., Hercules, CA).

Data analysis. Statistical analysis was performed using IBM SPSS statistics for Windows (version 22.0. IBM Corp.
Armonk, NY). Results of the G6PD variants from the previous study $^{24}$ and the current study were combined to obtain the prevalence of G6PD variants in SCT. The demographic data, G6PD genotypes, and allele frequencies are presented as the number and percentage values. The chi-square test was used to determine the association between G6PD variants and demographic data, as well as the association between G6PD (activity and genotype) and malaria infection. The allele frequency of each mutation variant was calculated using the Hardy-Weinberg equilibrium equation. The statistical significance level was set at $\alpha=0.05$.

Ethical review board. The study was approved by the Health Research Ethics Committee of the National Institute of Health Research and Development, Indonesia (Ethical approval number LB.02.01/2/KE.334/2018).

\section{RESULTS}

Demographic data of the sample population. The demographic data of a total of 381 samples are presented in Table 2. Of 381 samples, 225 (59\%) and 156 (41\%) samples were obtained from female and male subjects, respectively. The age was grouped according to the WHO guidelines. ${ }^{26}$ Three-hundred sixty-five (95.8\%) and 16 (4.2\%) samples were obtained from adults ( $>19$ years) and pediatrics ( $\leq 19$ years), respectively. Ethnicity was grouped as Timorese [348 (91.3\%) cases] and others, that is, Rotenese (20 cases, $5.2 \%$ ), Savunese (seven cases, 1.8\%), Sumbanese (one case, $0.3 \%$ ), Bataknese (one case, 0.3\%), Alorese (one case, 0.3\%), Buginese (one case, $0.3 \%$ ), Ambonese (one case, $0.3 \%$ ), and Belunese (one case, 0.3\%). Two-hundred twenty-six (59.3\%) samples were collected from the northern part of Indonesia: 76 (19.9\%), 70 (18.4\%), and 80 (21.0\%) samples from Oinlasi, Oe'ekam, and Oenino, respectively. One-hundred fifty-five (40.7\%) samples were obtained from the southern part: 67 (17.6\%) and 88 (23.1\%) samples from Panite and Batu Putih, respectively. Two-hundred twenty-five (59.1\%) samples were anemic, and 156 (40.9\%) samples were non-anemic (samples with normal hemoglobin levels). Based on PCR analysis, asymptomatic cases were detected in 181 (47.5\%) samples: 95 (24.9\%), 57 (15\%), and 29 (7.6\%) samples were $P$. vivax, $P$. falciparum, and mixed infection of $P$. falciparum and $P$. vivax, respectively. Based on G6PD screening by the Randox test, 96 (25.2\%) and 285 (74.8\%) samples were classified as G6PD deficient and G6PD normal, respectively.

Glucose 6-phosphate dehydrogenase variants. By combining the results of the previous study and the current

TABLE 1

PCR-RFLP conditions for the analysis of five variant glucose 6-phosphate dehydrogenase mutations

\begin{tabular}{|c|c|c|c|c|c|c|c|c|}
\hline $\begin{array}{l}\text { Primer } \\
\text { name }\end{array}$ & Primer's sequence $5^{\prime}-3^{\prime}$ & Exon & Name of the variant & $\begin{array}{c}\mathrm{T}\left({ }^{\circ} \mathrm{C}\right) \\
\text { annealing }\end{array}$ & $\begin{array}{l}\text { Amplicon } \\
\text { length (bp) }\end{array}$ & RE & Fragment size (bp) & References \\
\hline $95 \mathrm{~F}$ & CTC TAG AAA GGG GCT AAC TTC TCA & 2 & Gaohe $(95 A>G)$ & 60 & 198 & Mlul & N 198, M $174+24$ & $(34,48)$ \\
\hline 95R & GAT GCA CCC ATG ATG ATG AAT ACG & & & & & & & \\
\hline 487F & GCG TCT GAA TGA TGC AGC TCT GAT & 6 & Mahidol (487 G>A) & 60 & 104 & HindIII & N 104, M $82+22$ & $(18,48)$ \\
\hline 487R & CTC CAC GAT GAT GCG GTT CAA GC & & & & & & & \\
\hline $592 F$ & GAG GAG GTT CTG GCC TCT ACT C & 6 & Coimbra $(592 \mathrm{C}>\mathrm{T})$ & 65 & 240 & Pstl & N $157+83$ M $157+$ & $(34,48)$ \\
\hline 592R & TTG CCC AGG TAG TGG TCG CTG C & & & & & & $63+20$ & \\
\hline $1376 \mathrm{~F}$ & ACG TGA AGC TCC CTG ACG C & 12 & Canton (1376 G>T) & 62 & 214 & Affll & N 214 M $194+20$ & $(34,48)$ \\
\hline 1376R & GTG AAA ATA CGC CAG GCC TTA & & & & & & & \\
\hline KP-9F & ACG TGA AGC TCC CTG ACG C & 12 & Kaiping (1388G>A) & 65 & 227 & Ndel & N 227 M $206+21$ & $(18,34)$ \\
\hline KP-9R & GTG CAG CAG TGG GGT GAA CAT A & & & & & & & \\
\hline
\end{tabular}


TABLE 2

Demographic characteristics of the sample population from South Central Timor, Indonesia

\begin{tabular}{|c|c|}
\hline & Number of samples $(N=381), n(\%)$ \\
\hline \multicolumn{2}{|l|}{ Age-group $(\mathrm{WHO})^{\star}$} \\
\hline Pediatrics & $16(4.2)$ \\
\hline Adults & $365(95.8)$ \\
\hline \multicolumn{2}{|l|}{ Gender } \\
\hline Male & $156(40.9)$ \\
\hline Female & $225(59.1)$ \\
\hline \multicolumn{2}{|l|}{ Ethnicity } \\
\hline Timorese & 348 (91.3) \\
\hline Others & $33(8.7)$ \\
\hline \multicolumn{2}{|l|}{ Subdistrict group } \\
\hline Northern part & $226(59.3)$ \\
\hline Southern part & $155(40.7)$ \\
\hline \multicolumn{2}{|l|}{ Anemia status } \\
\hline Anemia† & $225(59.1)$ \\
\hline Normal & $156(40.9)$ \\
\hline \multicolumn{2}{|l|}{ Malaria infection (nested PCR) } \\
\hline P. falciparum & $57(15.0)$ \\
\hline P. vivax & $95(24.9)$ \\
\hline Mix (P. falciparum and $P$. vivax) & $29(7.6)$ \\
\hline Noninfected & $200(52.5)$ \\
\hline \multicolumn{2}{|c|}{ G6PD screening activity (Randox test)‡ } \\
\hline Normal & $285(74.8)$ \\
\hline Deficient & $96(25.2)$ \\
\hline
\end{tabular}

study, there are three G6PD variants found in SCT. Sixteen $(4.2 \%)$, two $(0.5 \%)$, and six (1.6\%) were G6PD Coimbra, Kaiping, and Vanua Lava variants, respectively. Samples that carried Coimbra and Kaiping G6PD variants were obtained from heterozygous females with allele frequencies 0.036 and 0.004 , respectively. Of Vanua Lava G6PD variants, 4, 1, and 1 samples were obtained from hemizygous males, a heterozygous female, and a homozygous female, respectively. The allele frequencies of the Vanua Lava variants were 0.007 in females and 0.026 in males. No samples carried other G6PD variants (Chatham, Viangchan, Gaohe, Canton, and Mahidol variants) (Table 3).

Factors associated with G6PD variants. The analysis of factors that could contribute to the distribution of G6PD is shown in Table 4. The distribution of G6PD Kaiping type in females was associated with ethnicity $(P=0.014)$. Based on the G6PD screening by the Randox test, G6PD deficiency was associated with heterozygous females having the Coimbra genotype $(P=0.011)$ and hemizygous males carrying the Vanua Lava variant $(P=0.001)$. However, normal G6PD was also reported by this test from eight female samples carrying the Coimbra variant, all female samples which have the Kaiping variant, and 1 from the homozygous female with the Vanua Lava variant.

Association between G6PD status and malaria infection. Glucose 6-phosphate dehydrogenase status in female and male subjects by the Randox test was associated with malaria infection (Table 5). In females, individuals with G6PD deficiency were associated with $P$. falciparum infection; the odds of infection were 0.0645 times of those with normal G6PD activity (OR $=0.0645$ [95\% Cl: $0.0085-0.4889] P=$ $0.008)$. No association was observed in $P$. vivax or mixed infections. In males, on the other hand, G6PD deficiency was associated with $P$. vivax infection; the odds of $P$. vivax infection was 0.1690 times of those with normal G6PD activity (OR = 0.1690 [95\% Cl: 0.0548-0.5208] $P=0.002$ ).

\section{DISCUSSION}

Malaria is still a major health problem in Indonesia, particularly in Eastern Indonesia. The program to achieve malaria elimination in Indonesia is to be carried out in four stages: 1) The Thousand Islands (Jakarta), and Bali and Batam islands in 2010; 2) Java, Aceh, and the Riau Islands in 2015; 3) Sumatra, West Nusa Tenggara, Kalimantan, and Sulawesi in 2020; and 4) Papua, West Papua, East Nusa Tenggara, and the Maluku Islands in 2030. ${ }^{1,27}$ Elimination is expected to be successful with the proper use of antimalarial drugs. The downside of radical treatment recommended by the Indonesian Ministry of Health (DHP combined with primaquine) is that primaquine can be toxic to people with G6PD deficiency. ${ }^{13,15,17,28,29}$

The results from this study were combined with those of the previous study conducted by Hutagalung and others. ${ }^{24}$ They showed that Coimbra was the most dominant G6PD variant in the SCT region, followed by Vanua Lava and Kaiping variants. The Vanua Lava variant was the dominant G6PD variant in Eastern Indonesia. ${ }^{18,21,22,25,30}$ A study by Kawamoto et al. ${ }^{31}$ reported that Kaiping and Coimbra mutation variants were prevalent on Flores Island, Eastern Indonesia, with frequencies of $50 \%$ and $9.1 \%$, respectively, among people of Sikka ethnicity. The prevalence of the Kaiping variant was $14.3 \%$ among members of Ende ethnicity, and the prevalence of the Coimbra variant was $5.6 \%$ among members of Bajo ethnicity. These two variants were also reported on Flores Island, with the frequency of $1.4 \%$ for the Coimbra variant, $0.8 \%$ for Kaiping together with Vanua Lava, Viangchan, and Chatham variants, each with a frequency of $0.3 \% .^{21}$ In another study in Eastern Indonesia, 11\% (5/44 cases) Coimbra variant

TABLE 3

Prevalence and allelic frequency of G6PD variants in South Central Timor, Indonesia

\begin{tabular}{|c|c|c|c|c|c|c|c|}
\hline Variant & Nucleotide substitution & Amino acid substitution & Ref SNP ID & Class & Number of samples, $n(\%)$ & Allele frequency & Female: male ratio \\
\hline Coimbra & $592 C>T$ & 198 Arg > Cys & rs137852330 & 2 & $16(4.2)$ & 0.036 (female) & $16: 0$ \\
\hline Kaiping & $1388 G>A$ & $463 \mathrm{Arg}>\mathrm{His}$ & rs72554664 & 2 & $2(0.5)$ & 0.004 (female) & $2: 0$ \\
\hline Gaohe & $95 A>G$ & $32 \mathrm{His}>\mathrm{Arg}$ & rs137852340 & 3 & $0(0)$ & - & - \\
\hline Mahidol & $487 \mathrm{G}>\mathrm{A}$ & 163 Gly > Ser & rs137852314 & 3 & $0(0)$ & - & - \\
\hline Canton & $1376 \mathrm{G}>\mathrm{T}$ & 459 Arg > Leu & rs72554665 & 3 & $0(0)$ & - & - \\
\hline Vanua Lava* & $10884 \mathrm{~T}>\mathrm{C}$ & 128 Leu > Pro & rs78365220 & 2 & $6(1.6)$ & 0.007 (female), 0.026 (male) & $2: 4$ \\
\hline Chatham* & $1003 G>A$ & 335 Ala $>$ Thr & rs5030869 & 2 & $0(0)$ & - & - \\
\hline Viangchan* & $871 G>A$ & $291 \mathrm{Val}>$ Met & rs137852327 & 3 & $0(0)$ & - & - \\
\hline
\end{tabular}

G6PD = glucose 6-phosphate dehydrogenase.

${ }^{*} \mathrm{G} 6 \mathrm{PD}$ variants were investigated in the previous study. ${ }^{24}$ 
TABLE 4

Factors associated with G6PD variants in female and male members of the South Central Timor population

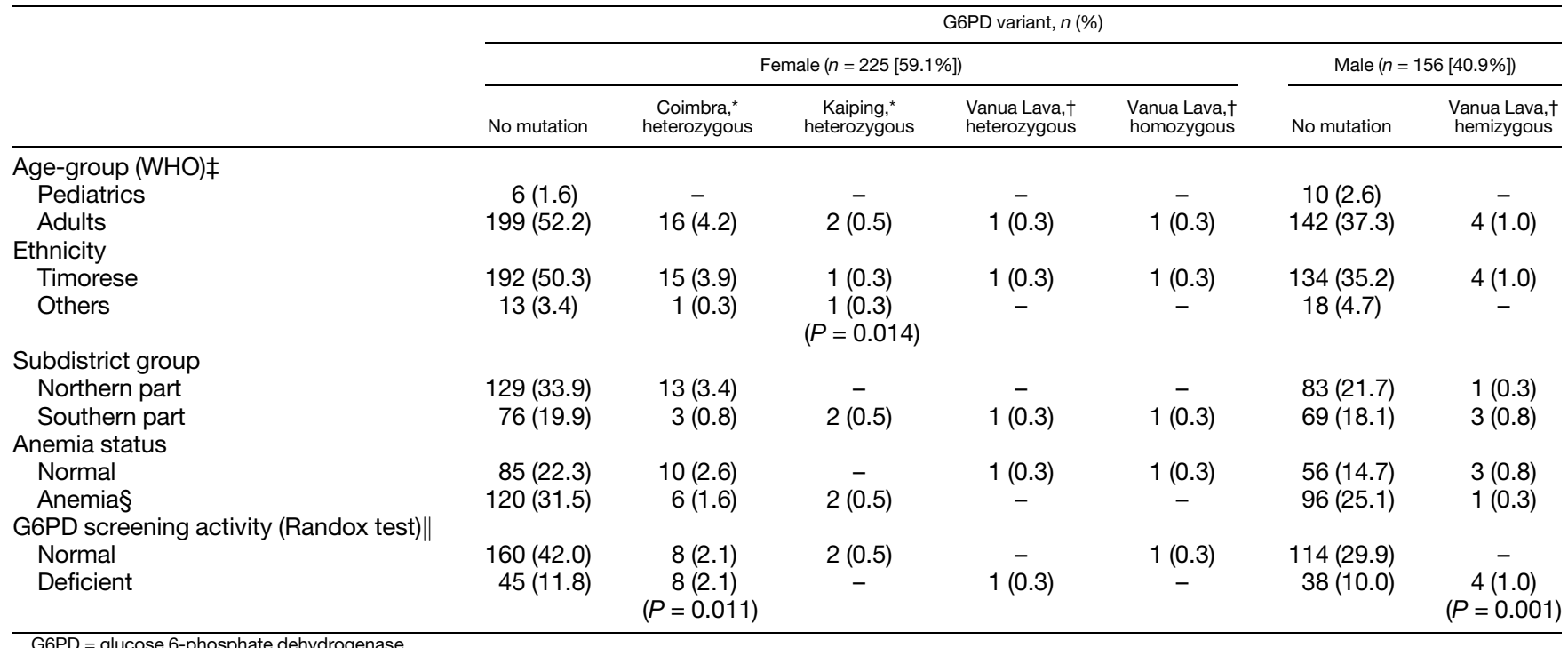

All carrier mutation samples were heterozygous

† Data from the previous study. ${ }^{24}$

$\ddagger$ Age-group (pediatrics $\leq 19$ years and adults $>19$ years).

$\S$ Anemia (male $<13 \mathrm{~g} / \mathrm{dL}$ and female $<11 \mathrm{~g} / \mathrm{dL}$ ).

$\|$ G6PD screening activity (normal $>6.97 \mathrm{U} / \mathrm{gHb}$ and deficient $\leq 6.97 \mathrm{U} / \mathrm{gHb}$ ).

frequency was reported among villagers of Panenggo Ede. ${ }^{18}$ A common variant in Asia, the Mahidol variant, was rarely reported in Java, West Indonesia. ${ }^{32}$ The G6PD Mahidol variant has been reported as a dominant G6PD mutation variant in the Thailand-Myanmar border population. ${ }^{33,34}$

Glucose 6-phosphate dehydrogenase Coimbra and Kaiping variants were classified as class II G6PD variants based on the WHO guidelines (class I, the most severe-class V, the mildest). ${ }^{35}$ The G6PD Coimbra and Mahidol variants were reported to be distributed in West Indonesia, whereas Viangchan, Kaiping, and Gaohe G6PD variants were reported in East Indonesia. However, it was noted that G6PD variants, which were found in Eastern Indonesia, were also found in western Indonesia and vice versa. ${ }^{36}$ This could be explained by the migration of people who have shared genes with the original population, and thus introducing the G6PD mutation genes. An inconclusive positive correlation was found between ethnicity and the Kaiping variant $(P=0.014)$, due to the small sample size of the Kaiping variant (only two samples) and Timorese being the most dominant ethnicity in population.

Based on the screening data by the Randox test from the previous study, 96 subjects $(25.2 \%)$ among the population were G6PD deficient. This number was different from the previous report (92 subjects were G6PD deficient) ${ }^{24}$ because four samples with a G6PD level $<6.97 \mathrm{U} / \mathrm{gHb}$ were misdiagnosed as normal. The G6PD activity based on the Randox test was associated with Coimbra genotypes $(P=0.011)$ and hemizygous males with the Vanua Lava variant $(P=0.001)$. This suggested a correlation between G6PD mutation and enzyme activity. However, normal G6PD activity was also found in the Coimbra variant (8/16 of heterozygous females), Kaiping variant (2/2 of heterozygous females), and Vanua Lava variant (1/2 homozygous female) (Table 4). These results indicated that the G6PD enzyme activity varied in heterozygous females. This phenomenon results from a mosaic effect of expression, as only one X-chromosome in each cell is active. Random inactivation of one or the other $\mathrm{X}$-chromosome (mosaicism) is due to lyonization, which results in heterozygous females having G6PD activities ranging between $0 \%$ and $100 \%$. The ratio of the two cell types that make up the mosaic is not the same in all females; thus, they can be expressed both as normal or deficient individuals. ${ }^{25,37,38}$ The qualitative tests most commonly used to check for G6PD deficiency in clinical settings are adequate for identifying males with G6PD deficiency, and therefore informing appropriate treatment options. However, these tests do not accurately define G6PD activity in females, especially in heterozygous females. Qualitative testing uses $30 \%$ of normal G6PD activity as the cutoff. $^{18}$ Because heterozygous females almost exclusively occupy intermediate G6PD enzyme-level phenotypes, mainly ranging from $30 \%$ to $80 \%$ of normal G6PD activity, qualitative screening tests for G6PD deficiency are insensitive above $30 \%$ of normal activity, and this leads to an increased risk of hemolysis by primaquine administration. ${ }^{39}$ A cohort study by Chu et al. ${ }^{40}$ in areas along the Thai-Myanmar border reported higher daily doses of primaquine as having the potential to cause clinically significant hemolysis in G6PD heterozygous females who are reported as phenotypically normal with pointof-care tests. Thus, molecular analysis may be required in heterozygous females for the disorder. ${ }^{41}$

Glucose 6-phosphate dehydrogenase-deficient subjects were less likely to be infected with malaria than non-deficient individuals. In females, deficient G6PD activity lowered $P$. falciparum infection to 0.0645 times compared with individuals with normal G6PD activity (OR $=0.0645$ [95\% Cl: 0.0085-0.4889] $P=0.008)$. In males, the deficient activity lowered the infection by $P$. vivax to 0.1690 times compared with individuals with normal G6PD activity $(\mathrm{OR}=0.1690[95 \% \mathrm{Cl}$ : $0.0548-0.5208] P=0.002)$. It is postulated that subjects with 
TABLE 5

Association between G6PD status and malaria infection in members of the South Central Timor population

\begin{tabular}{|c|c|c|c|c|c|}
\hline & & \multicolumn{4}{|c|}{ Malaria infection, $n(\%)$} \\
\hline & & Plasmodium falciparum & Plasmodium vivax & Mixed infection & Non-infection \\
\hline \multirow[t]{14}{*}{ Female $(n=225[59.1 \%])$} & G6PD screening activity (Randox test) ${ }^{\star}$ & & & & \\
\hline & Normal & $33(8.7)$ & $39(10.2)$ & $16(4.3)$ & $83(21.8)$ \\
\hline & Deficient & $\begin{array}{c}1(0.2) \\
\mathrm{OR}=0.0645 \\
(P=0.008)\end{array}$ & $12(3.2)$ & $2(0.5)$ & $39(10.2)$ \\
\hline & G6PD genotype & & & & \\
\hline & Coimbra $(592 \mathrm{C}>\mathrm{T}) \dagger$ & & & & \\
\hline & No mutation & $34(8.9)$ & $48(12.6)$ & $17(4.5)$ & $110(28.9)$ \\
\hline & Heterozygous & - & $3(0.8)$ & $1(0.3)$ & $12(3.1)$ \\
\hline & Kaiping $(1388 \mathrm{G}>\mathrm{A}) \dagger$ & & & & \\
\hline & No mutation & $34(8.9)$ & $51(13.4)$ & $18(4.8)$ & $120(31.5)$ \\
\hline & Heterozygous & - & - & - & $2(0.5)$ \\
\hline & Vanua Lava $(10884 T>C) \ddagger$ & & & & \\
\hline & No mutation & $33(8.7)$ & $51(13.4)$ & $18(4.7)$ & $121(31.7)$ \\
\hline & Heterozygous & - & - & - & $1(0.3)$ \\
\hline & Homozygous & $1(0.3)$ & - & - & - \\
\hline \multirow[t]{11}{*}{ Male $(n=156[40.9 \%])$} & G6PD screening activity (Randox test) ${ }^{\star}$ & & & & \\
\hline & Normal & $18(4.7)$ & $40(10.5)$ & $7(1.9)$ & 49 (12.9) \\
\hline & Deficient & $5(1.3)$ & $4(1.0)$ & $4(1.0)$ & $29(7.6)$ \\
\hline & & & $\begin{array}{c}\mathrm{OR}=0.1690 \\
(P=0.002)\end{array}$ & & \\
\hline & G6PD genotype & & & & \\
\hline & Coimbra $(592 \mathrm{C}>\mathrm{T}) \dagger$ & & & & \\
\hline & $\begin{array}{l}\text { No mutation } \\
\text { Kaiping }(1388 G>A)\end{array}$ & $23(6.0)$ & $44(11.5)$ & $11(2.9)$ & $78(20.5)$ \\
\hline & No mutation & $23(6.0)$ & $44(11.5)$ & $11(2.9)$ & $78(20.5)$ \\
\hline & Vanua Lava $(10884 T>C) \ddagger$ & & & & \\
\hline & No mutation & $23(6.0)$ & $43(11.3)$ & $11(2.9)$ & 75 (19.6) \\
\hline & Hemizygous & - & $1(0.3)$ & - & $3(0.8)$ \\
\hline
\end{tabular}

${ }^{*} \mathrm{G} 6 \mathrm{PD}$ screening activity (normal $>6.97 \mathrm{U} / \mathrm{gHb}$ and deficient $\leq 6.97 \mathrm{U} / \mathrm{gHb}$ ).

t All carrier mutation samples were heterozygous female.

$\ddagger$ Data from the previous study. ${ }^{24}$

G6PD deficiency are protected from malaria infection. ${ }^{20,42,43}$ According to Arese et al., ${ }^{42}$ mutations are considered protective if the following three evidence criteria are fulfilled: 1) geographical evidence (their distribution is geographically coincident with the present or historical distribution of malaria plasmodium, and their frequency is correlated with the severity of the disease), 2) epidemiological evidence (the carriers of protective mutations have lower mortality or less severe symptoms), and 3) mechanistic evidence (the mechanism of resistance is clarified by in vitro/in vivo studies). It is still too early to conclude that the results of this study have met the postulate because the hemoglobinopathic protection against malaria has not been substantiated according to those criteria. The possibility of protection against malaria by G6PD mutations deserves further investigation among the SCT population.

The demographic characteristics of the samples revealed that $181(47.5 \%)$ of them were asymptomatic malaria (PCR correction), with a majority of infections by $P$. vivax. A daily dose of $0.25 \mathrm{mg} / \mathrm{kg}$ primaquine for 14 days was recommended for the radical treatment of $P$. vivax patients with normal G6PD activity. ${ }^{13,17}$ This regimen could reduce the risk of primaquine-induced hemolysis due to unavailable G6PD testing in areas where $P$. vivax is prevalent. ${ }^{15,16}$ However, there were some reports that this regimen is less effective at preventing relapse. A study reported in 2017 by Douglas et al., ${ }^{44}$ in a hospital named Rumah Sakit Mitra Masyarakat, Timika, East Indonesia, compared the $P$. vivax treatment with DHP combined with primaquine versus DHP alone. This study followed the primaquine administration policy of 2006 , from a lower dose $(0.25 \mathrm{mg} / \mathrm{kg}$ given daily for 14 daysrecommended by Indonesian Ministry of Health) to a higher dose $(0.5 \mathrm{mg} / \mathrm{kg}$ given daily for 14 days $)$ for radical treatment of vivax. It found that among one-third of the patients who represented at the hospital with vivax malaria within 1 year, those treated with primaquine, were only $10 \%$ less likely to represent than those who had not received primaquine. Underdosing, as well as incomplete adherence to extended treatment regimens, could have contributed to the poor effectiveness of the drug. Another study of Indonesian soldiers with $P$. vivax acquired in Papua Province demonstrated that a supervised regimen of DHP with a high-dose primaquine regimen (30 mg daily dose or $45 \mathrm{mg}$ daily dose to subjects weighting $>70 \mathrm{~kg})$ had an excellent efficacy of $98 \%(95 \% \mathrm{Cl}:=$ 91-99\%). ${ }^{45}$ No studies in Indonesia demonstrated low-dose primaquine $(0.25 \mathrm{mg} / \mathrm{kg}$ daily for 14 days) efficacy. Considering several reports showing low efficacy of primaquine from malaria sites in Indonesia, the government should reconsider the low-dose primaquine policy for the radical treatment of vivax malaria. The WHO recommends $0.5 \mathrm{mg} / \mathrm{kg}$ daily for 14 days for patients with normal G6PD activity in areas where frequently relapsing strains of $P$. vivax are prevalent, ${ }^{14}$ with additional control for G6PD-deficient patients. Long regimens (14 days) of primaquine administration could play a role in poor adherence to this drug treatment. ${ }^{46}$ A recent study by Taylor et al., ${ }^{47}$ in Afghanistan, Ethiopia, Indonesia, and Vietnam, revealed a short-course 7-day-regimen primaquine was well tolerated and non-inferior to 14-day primaquine in patients with normal G6PD. The short-course regimen might improve 
adherence and the effectiveness of primaquine for radical cure of $P$. vivax malaria.

In conclusion, there are three G6PD variants (Coimbra, Kaiping, and Vanua Lava) observed in the SCT population. This information has added up on the G6PD genotypes in the population of malaria-endemic area in Indonesia. Molecular analysis of G6PD mutations may be required in vivax patients because of their risk of hemolysis under primaquine treatment. Besides the existing program to prevent artemisinin resistance, Indonesia should evaluate the low-dose primaquine policy for vivax radical cure.

Received October 22, 2019. Accepted for publication June 5, 2020.

Published online June 29, 2020.

Acknowledgments: We thank all staff of pharmaceutical, parasitology, and bacteriology laboratories of Biomedical and Basic Health Technology, NIHRD, Ministry of Health of the Republic of Indonesia. And, we would like to thank Dawid Krenc for editing English.

Financial support: This study was jointly supported by Chulabhorn International College of Medicine, Thammasat University, Center of Excellence in Pharmacology and Malaria and Cholangiocarcinoma, Thammasat University, and the National Institute of Health Research and Development, the Ministry of Health of the Republic of Indonesia. N. S. gratefully acknowledges the financial support provided by Thammasat University Research Fund under Thammasat University Research Scholar, Contract No. 136/2560, Menzies School of Health, Australia, for all the secondary data used in this study through Asia Pacific Malaria Elimination Network (APMEN), Project No. 103-02.

Authors' addresses: Novi Sulistyaningrum and Dona Arlinda, Chulabhorn International College of Medicine (CICM), Thammasat University (Rangsit Campus), Patum Thani, Thailand, and National Institute of Health Research and Development, Ministry of Health, Republic of Indonesia, Jakarta, Indonesia, E-mails: novisulistya@ yahoo.co.id and arlindona@yahoo.co.id. Jontari Hutagalung, Sunarno Sunarno, Intan Sari Oktoberia, Sarwo Handayani, Riyanti Ekowatiningsih, Endah Ariyanti Yusnita, Budi Prasetyorini, and Aulia Rizki, National Institute of Health Research and Development, Ministry of Health, Republic of Indonesia, Jakarta, Indonesia, E-mails: jontarihutagalung@ yahoo.com,no_nar@yahoo.com, intan.sarioktoberia@gmail.com, menik25@gmail.com, ririn_joko@yahoo.co.id, endaha6881@gmail.com, rinibpr@gmail.com, and laurentiaklara@gmail.com. Emiliana Tjitra, St. Carolus Hospital, Jakarta, Indonesia, E-mail: emil.tjitra@gmail.com. Kesara Na-Bangchang and Wanna Chaijaroenkul, Chulabhorn International College of Medicine (CICM), Thammasat University (Rangsit Campus), Patum Thani, Thailand, E-mails: kesaratmu@hotmail.com and wn_ap39@yahoo.com.

\section{REFERENCES}

1. Republic of Indonesia, 2009. Keputusan Menteri Kesehatan Nomor 293/Menkes/SK/IV/2009 tentang Eliminasi Malaria di Indonesia. Jakarta, Indonesia: Ministry of Health Republic of Indonesia.

2. Directorat P2B2, 2017. Buku Petunjuk Teknis Penyelidikan Epidemiologi Malaria Dan Pemetaan Wilayah Fokus (Daerah Eliminasi Dan Pemeliharaan). Jakarta, Indonesia: Ministry of Health Republic of Indonesia.

3. World Health Organization, 2017. World Malaria Report 2017. Geneva, Switzerland: WHO Press.

4. NIHRD, 2013. Hasil Riskesdas 2013. Jakarta, Indonesia: Ministry of Health Republic of Indonesia.

5. NIHRD, 2019. Laporan Nasional Riskesdas 2018. Jakarta, Indonesia: Lembaga Penerbit Badan Penelitian dan Pengembangan Kesehatan (LPB).

6. Hutagalung $\mathrm{J}$ et al., 2016. Kajian ilmiah pre-eliminasi malaria di Wilayah Timur Indonesia. OSIR 9: 1-7.

7. World Health Organization, 2015. Control and Elimination of Plasmodium Vivax Malaria: A Technical Brief. Geneva, Switzerland: WHO Press.

8. Price RN, Seidlein Lv, Valecha N, Nosten F, Baird JK, White NJ, 2014. Global extent of chloroquine-resistant Plasmodium vivax: a systematic review and meta-analysis. Lancet Infect Dis 14: 982-991.

9. Tjitra E, Pribadi W, Raharjo K, Budiono W, Arbani P, Naibaho P, Supriyanto S, Romzan A, Dewi RM, Gunawan S, 1996. Treatment of uncomplicated in vitro chloroquine resistant falciparum malaria with artemether in Irian Jaya. Med J Indones 5: 33-41.

10. Tjitra E, Anstey NM, Sugiarto $P$, Warikar N, Kenangalem E, Karyana M, Lampah DA, Price RN, 2008. Multidrug-resistant Plasmodium vivax associated with severe and fatal malaria: a prospective study in Papua, Indonesia. PLoS Med 5: e128.

11. Fryauff DJ, Tuti S, Mardi A, Masbar S, Patipelohi R, Leksana B, Kain KC, Bangs MJ, Richie TL, Baird JK, 1998. Chloroquineresistant Plasmodium vivax in transmigration settlements of West Kalimantan, Indonesia. Am J Trop Med Hyg 59: 513-518.

12. Sutanto I, Suprijanto S, Manoempil P, Baird JK, 2009. Resistance to chloroquine by Plasmodium vivax at Alor in the lesser sundas archipelago in Eastern Indonesia. Am J Trop Med Hyg 81: 338-342.

13. Direktorat Jenderal P2P, 2018. Buku Saku Tatalaksana Kasus Malaria. Jakarta, Indonesia: Ministry of Health Republic of Indonesia.

14. World Health Organization, 2015. Guideline for the Treatment of Malaria, 3rd edition. Geneva, Switzerland: WHO Press.

15. Recht J, Ashley EA, White NJ, 2018. Use of primaquine and glucose-6-phosphate dehydrogenase deficiency testing: divergent policies and practices in malaria endemic countries. PLoS Negl Trop Dis 12: e0006230.

16. Surjadjaja C, Surya A, Baird JK, 2016. Epidemiology of Plasmodium vivax in Indonesia. Am J Trop Med Hyg 95: 121-132.

17. Kusriastuti R, Surya A, 2012. New treatment policy of malaria as a part of malaria control programme. Acta Med Indones 44: 265-269.

18. Satyagraha AW et al., 2016. Assessment of point-of-care diagnostics for G6PD deficiency in malaria endemic rural Eastern Indonesia. PLoS Negl Trop Dis 10: e0004457.

19. World Health Organization, 2018. Guide to G6PD Deficiency Rapid Diagnostic Testing to Support P. vivax Radical Cure. Geneva, Switzerland: WHO Press.

20. Goo YK, Ji SY, Shin HI, Moon JH, Cho SH, Lee WJ, Kim JY, 2014. First evaluation of glucose-6-phosphate dehydrogenase (G6PD) deficiency in vivax malaria endemic regions in the Republic of Korea. PLoS One 9: e97390.

21. Matsuoka H, Arai M, Yoshida S, Tantular IS, Pusarawati S, Kerong $\mathrm{H}$, Kawamoto F, 2003. Five different glucose-6-phosphate dehydrogenase (G6PD) variants found among 11 G6PDdeficient persons in Flores Island, Indonesia. J Hum Genet 48: 541-544.

22. Tantular IS, Matsuoka H, Kasahara $\mathrm{Y}$, Pusarawati S, Kanbe T, Tuda JSB, Kido Y, Dachlan YP, Kawamoto F, 2010. Incidence and mutation analysis of glucose-6-phosphate dehydrogenase deficiency in Eastern Indonesian populations. Acta Med Okayama 64: 367-373.

23. Gomez-Manzo S et al., 2016. Glucose-6-phosphate dehydrogenase: update and analysis of new mutations around the world. Int J Mol Sci 17: e2069.

24. Hutagalung $J$, Kusnanto $H$, Supargiyono $S$, Sadewa $A H$, Satyagraha AW, 2015. The first evaluation of glucose-6phosphate dehydrogenase deficiency (G6PD) gene mutation in malaria endemic region at South Central Timor (SCT) district, Eastern Indonesia 2014-2015. Indones J Biotechnol 20: 117-132.

25. Satyagraha AW et al., 2015. G6PD deficiency at Sumba in Eastern Indonesia is prevalent, diverse and severe: implications for primaquine therapy against relapsing vivax malaria. PLoS Negl Trop Dis 9: e0003602.

26. World Health Organization, 2013. Consolidated Guidelines on the Use of Antiretroviral Drugs for Treating and Preventing HIV Infection: Recommendations for a Public Health Approach June 2013. Geneva, Switzerland: WHO Press.

27. Elyazar IRF, Hay SI, Baird JK, 2011. Malaria distribution, prevalence, drug resistance and control in Indonesia. Adv Parasitol 74: 41-175.

28. Baird K, 2015. Origins and implications of neglect of G6PD deficiency and primaquine toxicity in Plasmodium vivax malaria. Pathog Glob Health 109: 93-106. 
29. Ley B et al., 2017. Barriers to routine G6PD testing prior to treatment with primaquine. Malar J 16: 329.

30. Howes RE et al., 2013. Spatial distribution of G6PD deficiency variants across malaria-endemic regions. Malar J 12: 418.

31. Kawamoto F, Matsuoka H, Kanbe T, Tantular IS, Pusarawati S, Kerong HI, Damianus W, Mere D, Dachlan YP, 2006. Further investigations of glucose-6-phosphate dehydrogenase variants in Flores Island, Eastern Indonesia. J Hum Genet 51: 952-957.

32. Soemantri AG, Saha S, Saha N, Tay JSH, 1995. Molecular variants of red cell glucose-6-phosphate dehydrogenase deficiency in Central Java, Indonesia. Hum Hered 45: 346-350.

33. Bancone G, Chu CS, Somsakchaicharoen R, Chowwiwat N, Parker DM, Charunwatthana P, White NJ, Nosten FH, 2014. Characterization of G6PD genotypes and phenotypes on the northwestern Thailand-Myanmar border. PLoS One 9: e116063.

34. Phompradit P, Kuesap J, Chaijaroenkul W, Rueangweerayut R, Hongkaew Y, Yamnuan R, Na-Bangchang K, 2011. Prevalence and distribution of glucose-6-phosphate dehydrogenase (G6PD) variants in Thai and Burmese populations in malaria endemic areas of Thailand. Malar J 10: 368.

35. WHO Working Group, 1989. Glucose-6-phosphate dehydrogenase deficiency. Bull World Health Organ 67: 601-611.

36. Omega M, Banard RT, 2013. Phylogeny and origin of glucose-6phosphate dehydrogenase (G6PD) deficiency mutations in Indonesia. Indones J Biotechnol 18: 14-25.

37. Howes RE, Battle KE, Satyagraha AW, Baird JK, Hay SI, 2013. G6PD deficiency: global distribution, genetic variants and primaquine therapy. Adv Parasitol 81: 133-201.

38. Chu CS, Bancone G, Nosten F, White NJ, Luzzato L, 2018. Primaquine-induced haemolysis in females heterozygous for G6PD deficiency. Malar J 17: 101

39. Domingo GJ, Advani N, Satyagraha AW, Sibley CH, Rowley E, Kalnoky M, Cohen J, Parker M, Kelley M, 2019. Addressing the gender-knowledge gap in glucose-6-phosphate dehydrogenase deficiency: challenges and opportunities. Int Health 11: 7-14.

40. Chu CS et al., 2017. Haemolysis in G6PD heterozygous females treated with primaquine for Plasmodium vivax malaria: a nested cohort in a trial of radical curative regimens. PLoS Med 14: e1002224.

41. Belfield KD, Tichy EM, 2018. Review and drug therapy implications of glucose-6-phosphate dehydrogenase deficiency. $A m \mathrm{~J}$ Health Syst Pharm 75: 97-104.

42. Arese $P$, Pantaleo A, Turrini F, 2015. Encyclopedia of Malaria. New York, NY: Springer Science+Business Media, 1-18.

43. Manjurano A et al., 2015. African glucose-6-phosphate dehydrogenase alleles associated with protection from severe malaria in heterozygous females in Tanzania. PLoS Genet 11: e1004960.

44. Douglas NM, Poespoprodjo JR, Patriani D, Malloy MJ, Kenangalem E, Sugiarto P, Simpson JA, Soenarto Y, Anstey NM, Price RN, 2017. Unsupervised primaquine for the treatment of Plasmodium vivax malaria relapses in southern Papua: a hospital-based cohort study. PLoS Med 14: e1002379.

45. Sutanto I et al., 2013. Randomized, open-label trial of primaquine against vivax malaria relapse in Indonesia. Antimicrob Agents Chemother 57: 1128-1135.

46. Thriemer K et al., 2018. Quantifying primaquine effectiveness and improving adherence: a round table discussion of the APMEN vivax working group. Malar J 17: 241.

47. Taylor WR et al., 2019. Short-course primaquine for the radical cure of Plasmodium vivax malaria: a multicentre, randomised, placebo-controlled non-inferiority trial. Lancet 394: 929-938.

48. Huang CS, Hung KL, Huang MJ, Li YC, Liu TH, Tang TK, 1996. Neonatal jaundice and molecular mutations in Glucose-6phosphate dehydrogenase deficient newborn infants. Am J Hematol 51: 19-25. 